Arq. Bras. Med. Vet. Zootec., v.69, n.4, p.771-776, 2017

\title{
Applicability of polyamide 12 intramedullary locked rods in the stabilization of induced humeral fracture in cockerels (white plymouth rock) - in vivo study
}

[Aplicabilidade da haste intramedular bloqueada de poliamida 12 na estabilização de fratura umeral induzida em galos (Plymouth Rock Branca) - estudo in vivo]

\author{
E.P. Cherobini ${ }^{1}$, L.L. Carvalho ${ }^{1}$, D.O. Garcia ${ }^{1}$, F.G.G. Dias ${ }^{1}$, C.A.S. Malta ${ }^{1}$, A.C. Facin ${ }^{2}$, \\ E. Mattos-Junior ${ }^{1}$, G.M. Magalhães ${ }^{3}$, L.G.G.G. Dias ${ }^{2} *$ \\ ${ }^{1}$ Universidade de Franca - Unifran - Franca, SP \\ ${ }^{2}$ Universidade Estadual Paulista "Júlio Mesquita Filho" - Unesp - Jaboticabal, SP \\ ${ }^{3}$ Instituto Federal do Sul de Minas - Muzambinho, MG
}

\begin{abstract}
The aim of this study was to evaluate the use of polyamide 12 intramedullary rods in osteotomized humerus in cockerels (White Plymouth Rock) and analyze, by radiography and histopathology, bone consolidation and the formation of bone callus. Ten cockerels were subjected to transverse osteotomy of the right humeral diaphysis followed by the insertion of polyamide 12 locked rods, with two nails in each bone fragment. Radiographies obtained at the immediate pre and post-operative period, and every 7 days for 3 months revealed no perioperatory complications. Radiography revealed a radiopaque bone callus between the 4th and 5th week post-surgery. Histopathology detected an amphophylic material (polyamide 12 rod) in the intramedullary region and the proliferation of highly vascularized connective tissue between the rod and the cortical bone. This connective tissue was highly cellular with differentiation into osteoblasts. The collagen fibers varied from loose to dense and a differentiated bone matrix, containing osteocytes in gaps and the development of bone marrow, was also observed; indicating the formation of a bone callus without signs of implant rejection. The polyamide 12 intramedullary rod was effective in the stabilization of the fractures used in this experimental model, with no rejection reaction for at least 90 days.
\end{abstract}

Keywords: avian, osteosynthesis, orthopaedics, bone union, milling

\section{RESUMO}

O presente estudo teve como objetivo avaliar a implantação de hastes intramedulares de poliamida 12, em úmeros osteotomizados de galos (Plymouth Rock Branca), bem como avaliar a consolidação óssea, por meio da verificação da formação de calo ósseo, analisando exames radiográficos e histopatológicos. Os galos foram submetidos à osteotomia transversa da diáfise do úmero direito, sendo implantadas posteriormente as hastes de poliamida 12 bloqueada com dois parafusos em cada fragmento ósseo. Após o procedimento cirúrgico, foram realizadas radiografias nos momentos pré e pós-operatório imediato e, posteriormente, a cada sete dias, durante três meses, até a realização da eutanásia. Não houve complicações perioperatórias. Ao exame radiográfico, os animais apresentaram formação de calo ósseo radiopaco entre a quarta e quinta semanas de pós-operatório. Ao exame histopatológico, foi possível notar, em todos os animais, presença de material anfofílico (haste de poliamida 12) ocupando a região intramedular óssea, e entre a haste e as corticais ósseas, proliferação de tecido conjuntivo altamente vascularizado. Tal tecido apresentou-se altamente celular com diferenciação em osteoblastos. Notaram-se também fibras colágenas, variando de aspecto frouxo a denso, e observou-se formação de matriz óssea diferenciada com osteócitos em lacunas e formações de medula óssea, denotando formação de calo ósseo sem sinais de rejeição do implante. A haste intramedular de poliamida 12 foi eficaz para estabilização das fraturas utilizando-se esse modelo experimental, sem reação de rejeição pelo período de 90 dias.

Palavras-chave: aves, osteossíntese, ortopedia, união óssea, fresagem

Recebido em 15 de setembro de 2016

Aceito em 13 de outubro de 2016

*Autor para correspondência (corresponding author)

E-mail: gustavogosuen@fcav.unesp.br 


\section{INTRODUCTION}

As with other species, birds are subject to traumatic bone lesions, especially humeral and tibial-tarsal fractures. In animals raised in captivity, these fractures occur as a result of falls and crushes in cages; while in the wild, they result from entanglement in electric cables, fences, wires, glass, road traffic accidents, and firearms (Bolson et al., 2005; Bolson and Schossler, 2008).

Osteosynthesis in birds is challenging due to the clinical state of the animals at arrival at the rehabilitation centres and the need for maximum anatomical and functional recovery of the fractured bone, especially thoracic ones (Quirós et al., 2002; Gouvêa et al., 2011).

Several factors must be considered when choosing the best material and rigid fixation method for osteosynthesis in birds, such as the biological characteristics and the type of activities related to the future function of the affected member (Bennett, 1997). Other factors inherent to surgical complexity in birds are the ample medullary canal, the high levels of calcium, and the pneumatic aspect of the bones (Bush, 1977; Bolson and Schossler, 2008).

The aim of this study was to analyse the applicability of polyamide 12 locked rods in induced transverse fractures of the humeral diaphysis in cockerels (White Plymouth Rock) and to evaluate bone callus formation through radiography and histopathology.

\section{MATERIAL AND METHODS}

This study was approved by the Ethics Committee in the Use of Animals of the Universidade de Franca, Franca-SP, Brazil (protocol number 041/12) and followed the guidelines provided by the Brazilian Society of Laboratory Animal Science (Sociedade Brasileira de Ciência de Animais de Laboratório). All the procedures were carried out by the same trained professionals.

Ten clinically healthy cockerels (White Plymouth Rock), obtained from a commercial breeder at 15 days old and with no macroscopic anatomical deformity, were acclimatized in individual $1 \mathrm{~m}^{2}$ cages in temperate enclosure. A commercial feed specific for the species was provided daily and water was available ad libitum until animals reached 60 days of age and were then subjected to the surgical procedure. Food fasting was introduced two hours prior to surgery.

The polyamide 12 rods were produced by selective laser sintering at the Centro de Tecnologia da Informação Renato Archer, "Tridimensional Technology Division", Campinas - SP, Brazil. The rods were solid, 4 $\mathrm{mm}$ wide, and $120 \mathrm{~mm}$ long. Conventional selfdrilling stainless steel orthopaedic screws of $2 \mathrm{~mm}$ diameter and variable lengths were used for the locking of the rods.

Animals were pre-medicated with Ketamine (10 $\mathrm{mg} / \mathrm{kg}$ ) combined with Butorphanol $(1 \mathrm{mg} / \mathrm{kg})$ in a single syringe and applied in the pectoral muscle. Anaesthetic induction was carried out with isofluorane using a facial mask. Subsequently, the animals were intubated with an orotracheal tube and anaesthesia maintained with the same anaesthetic agent diluted in $100 \%$ oxygen, at an adequate concentration. Blocking of the right brachial plexus was performed with lidocaine without vasoconstrictor $(5 \mathrm{mg} / \mathrm{kg})$.

At the end of radiographic analysis (90 days post-operative), the animals were subjected to chemical immobilization with Ketamine $(30 \mathrm{mg} / \mathrm{kg})$ and Xylazine $(0.5 \mathrm{mg} / \mathrm{kg})$ given intramuscular (IM). After 10 minutes, percutaneous venous access was obtained at the axillary vein for administration of sodium thiopental $(50 \mathrm{mg} / \mathrm{kg})$. Death was confirmed by the absence of a heartbeat and respiratory movements.

Animals were placed in left lateral decubitus and the feathers plucked from the lower region of the neck (right side) to the tip of the right wing, $360^{\circ}$, extending to the sides (breast and back). Standard surgical asepsis was performed. Dorsolateral access was used to reach the right humerus and, following bone exposure, complete transversal osteotomy of the humeral diaphysis was performed using an odontology saw under continuous irrigation. Subsequently, with the use of a battery-operated drill and bit, perforation was carried out from the osteotomy line to the greater tubercle of the humerus. The same procedure was then performed using a manual drill (Fig 1A). The polyamide 12 intramedullary rod was manually inserted from the fracture line towards the proximal humeral fragment and, when necessary, a mallet was used to aid 
insertion (Fig 1B). The rod was then fixed with screws in the cortical bone. The positioning of the screws followed the lateromedial disposition of the humerus (Fig 1C).

Post-operative analgesia consisted of meloxicam $(0.1 \mathrm{mg} / \mathrm{kg})$ and butorphanol $(1 \mathrm{mg} / \mathrm{kg})$ IM every 24 hours, for 4 days. Prophylactic antibiotic therapy with enrofloxacin $(20 \mathrm{mg} / \mathrm{kg})$ was given every 24 hours, for 4 days. Physical-orthopaedic examinations of the operated wing were carried out daily in all animals and the surgical wound cleaned with gauze and saline solution until the removal of the skin suture at 15 days postsurgery.

Radiographic evaluation was carried out immediately before and after the surgical procedure and, subsequently, every 7 days up to 90 days post-surgery. Craniocaudal and mediolateral projections of the operated humerus were analysed.

After humerus removal, a $0.5 \mathrm{~cm}$ bone fragment containing the bone callus was sampled at the fracture site and individually fixed in $10 \%$ formalin solution for analysis at the Pathology Sector of the Universidade de FrancaUNIFRAN, Franca-SP, Brazil. The fragments were decalcified in tetrasodium EDTA, chloric acid, and potassium sodium tartrate solution prior to dehydration, diaphonization, and embedding in paraffin. Sections $(5 \mu \mathrm{m})$ were stained with Haematoxylin and Eosin (HE), and Masson Trichrome (MT). Analysis of predominant cell type, presence of bone matrix, and collagen fibres was performed using a light microscope at 400x magnification.

\section{RESULTS AND DISCUSSION}

From acquisition to euthanasia, the animals showed progressive weight gain with no signs suggestive of loss of homeostasis in the body. There were no intercurrences with the cleaning and disinfection of the cages or the transport of the animals for radiographic evaluation.

The anaesthetic procedure followed the recommendation for birds (Hatt 2002; Gouvêa et $a l ., 2011)$ and there were no intra-operative intercurrences. Mean surgical time was $40 \pm 3$ minutes.
According to Wissman (1999) and Bolson and Schosler (2008), great care must be taken with fractures of the humerus as it is a pneumatic bone that communicates with the clavicular and cranial thoracic air sacs, which in turn communicate with the adjacent lung. In the present study, no respiratory changes were observed at the pre, trans, or post-operative period even after osteotomy of the diaphysis of the humerus, perforation, manual drilling, and insertion of the polyamide 12 rods. These findings indicate that this procedure is notably executable. There was no contamination, pneumonia, or air sacculitis during the surgical procedure or the post-operative period.

According to Tully (2002) and Bolson and Schosler (2008), the aim and the techniques employed in avian osteosynthesis are similar to mammals. Thus, taking into consideration the above statement, the diameter of the medullary canal of the humerus (Alievi et al., 2008) and the need for the majority of birds to return to the wild (Quirós et al. 2002; Gouvêa et al., 2011), the present study used locked rods in order to hypothetically provide good stabilization without the need for further surgical intervention for its removal.

The polyamide 12 rod was selected for being light, easy to purchase and autoclave, low cost, and for enabling the use of locking screws in any desired direction; which in turn promotes the fixation of the fractured bone fragments and potential chips, and annuls the forces at the fracture site. Thus, the polyamide 12 rod showed greater benefits than the other implants conventionally used in birds.

Rod insertion did not cause lesion to the radial nerve during humeral osteosynthesis, nor damage to the shoulder or elbow joints. The use of intramedullary implants often lead to damages to joints, ligaments, and tendons (Martin and Ritchie, 1994; Degernes et al., 1998); however, the animals in the present study did not show such problems at the daily clinical evaluations, corroborating with the findings by Castro et al. (2004) who used a metal intramedullary pin in psittacines. This suggests that minimal surgical procedures are essential to avoid damages to anatomic structures and provide adequate flight recovery. 


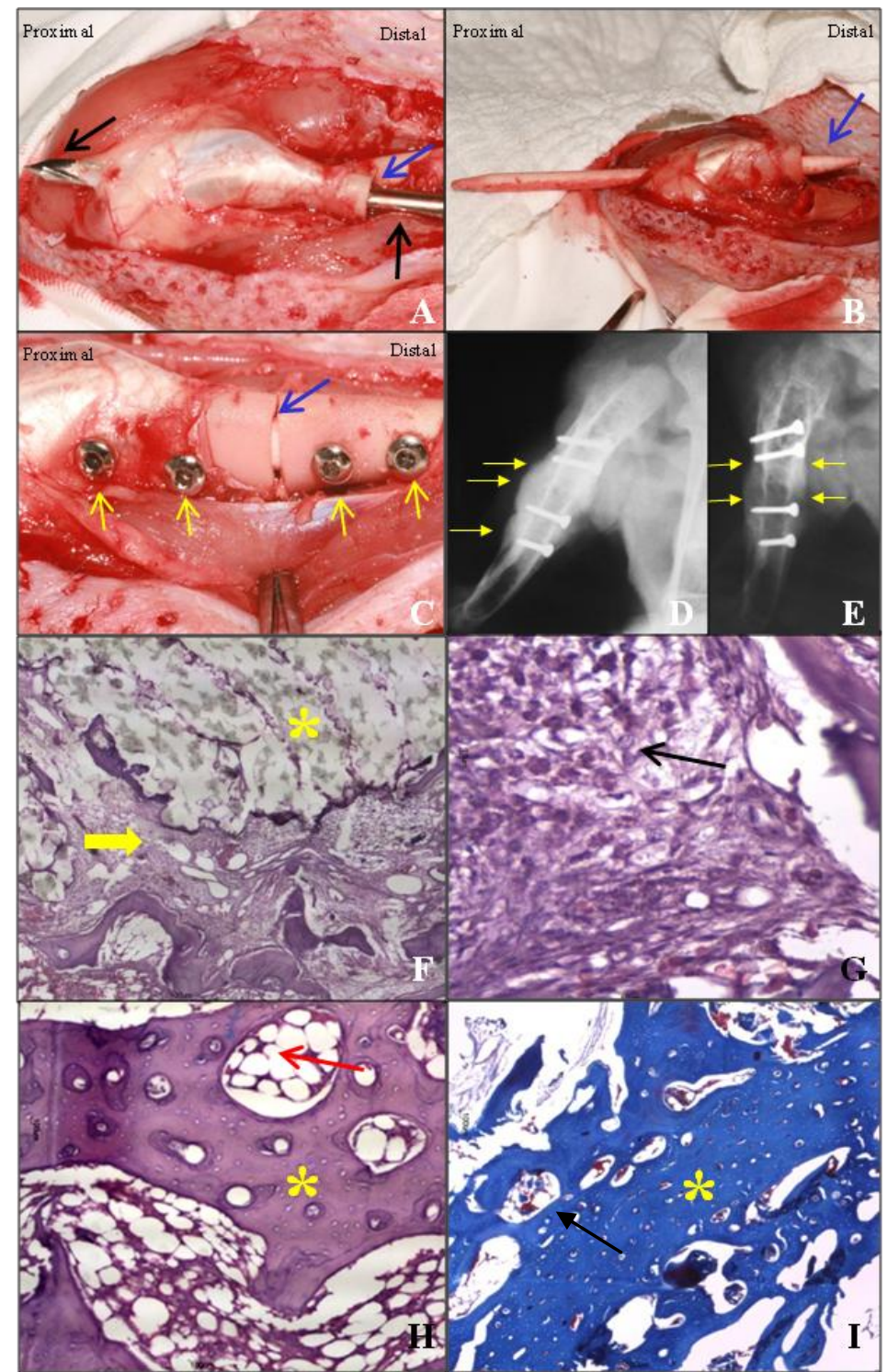

Figure 1. Photographic, radiographic and photomicrographic images of the stabilization of induced humeral fracture using polyamide 12 rods in cockerels (White Plymouth Rock). A. Photographic image of the drilling of the proximal fragment of the right humerus (drill bit $4 \mathrm{~mm}$ diameter- black arrows), note the osteotomy site in the diaphysis of the humerus (blue arrow); B. Photographic image highlighting the polyamide 12 intramedullary rod inserted into the proximal fragment of the humerus by the normograde way, with visible portion at the fracture site (blue arrow); C. Photographic image illustrating the reduced fracture of the humerus (blue arrow) interlocked with four stainless steel screws (yellow arrows indicate the screws head); D and E. Radiographic images of the right humerus stabilized with a polyamide 12 intramedullary locked rod at 28 and 35 days post-operatively, respectively; D. High bone activity of callus development (arrows), radiolucent polyamide 12; E. Start of bone callus remodelling (yellow arrows); F. Photomicrography of the bone tissue collected from the bone callus, 4x magnification, HE. Note the polyamide 12 rod $(*)$ adjacent to the highly vascularized connective tissue (arrow); G. Photomicrography of the bone tissue (humerus), 40x magnification, HE. Presence of osteoblasts (arrow) interspersed by bone matrix; H. Photomicrography of the bone tissue (humerus), 10x magnification, HE. Highly differentiated tissue $(*)$ and formation of bone marrow (arrow); I. Photomicrography of highly differentiated bone tissue (humerus), 10x magnification, MT. Bone tissue stained in blue (*) with bone marrow (arrow). HE: Haematoxylin-Eosin, MT: Masson Trichrome. 
Radiographic evaluation was performed every 7 days, as previously suggested by Yamazoe et al. (1994) due to the fast metabolism of birds, which leads to alterations happening sooner than in mammals. Bone consolidation was observed by $\mathrm{X}$-ray in all animals between the $4^{\text {th }}$ and $5^{\text {th }}$ week of evaluation, in agreement with Wissman (1999), who reported the mineralization of the callus in birds between 3 and 6 weeks (Figu 1D and $1 \mathrm{E})$. However, stability was only noticeable by palpation between 18 and 21 days postsurgery, as a result of the great increase in the size of the callus.

The samples analysed under light microscopy did not show histopathological variations between the animals and the presence of an amphophylic material (polyamide 12) was observed in the intramedullary region (Fig $1 \mathrm{~F}$ ). At the site of insertion of the polyamide 12 rod, the proliferation of a highly vascularized connective tissue was observed between the medullary to the cortical regions. This tissue was highly cellular, with differentiation into osteoblasts (Fig 1G) and the collagen fibres present varied from loose to dense and stained blue by the Masson Trichrome dye.

In the periphery, it was possible to observe the formation of a differentiated bone matrix, with osteocytes in gaps and the development of bone marrow (Fig 1H). All highly differentiated bone matrixes stained blue by the Masson Trichrome dye (Fig 1I).

Cockerels (White Plymouth Rock) proved to be an adequate experimental model for fractures in birds and the use of the humerus for osteotomy did not compromise the ventilation of the animals. Furthermore, polyamide 12 rods could have clinical applicability in avian osteosynthesis; however, further clinical studies, over longer periods of time, are necessary.

\section{CONCLUSIONS}

Based on the results from this study it can be concluded that the intramedullary polyamide 12 rod was effective in the correction of experimentally induced transversal fractures of the humerus in cockerels, providing stabilization of the fracture site and consolidation, as well as displaying histopathological characteristics inherent to the bone tissue up to 90 days postsurgery.

\section{REFERENCES}

ALIEVI, M.M.; OLIVEIRA, A.N.C.; FERREIRA, P.A. et al. Osteossíntese de úmero em pombos domésticos (Columbalivia) associando-se pinos metálicos e polimetilmetacrilato intramedulares após osteotomia diafisária. Arq. Bras. Med. Vet. Zootec., v.60, p.843-850, 2008.

BENNETT, T.R.A. Orthopedic surgery. In: ALTMAN, R.B.; CLUBB, S.L.; DORRESTEIN, G.M.; QUESSENBERRY, K. (Eds.). Avian medicine and surgery. Fhiladelphia: WB Saunders, 1997. p.733-766.

BOLSON, J.; SCHOSSLER, J.E.W. Osteossíntese em aves - revisão da literatura. Arq. Ciênc. Vet. Zoo. Unipar, v.11, p.55-62, 2008.

BOLSON, J.; ORNES, R.S.J.E.; MOTTIN, V. Osteossintese umeral em pombos domésticos (Columbalivia) com a utilização de pino intramedular estabilizado externamente com barra acrílica. Salador: Associação Nacional Clínica Veteterinária Pequenos Animais, 2005. p.30-32.

BUSH, M. External fixation of avian fractures. $J$. Am. Vet. Med. Assoc., v.171, p.943-946, 1977.

CASTRO, P.F.; MATERA, J.M.; FANTONI, D.T.; GUIMARÃES, M.R. Uso de pino de aço intramedular na reparação de fraturas de ossos longos em psitacídeos:arara-azul (Anodorhynchushyacinthinus), arara-canindé (Ara ararauna) e papagaio-verdadeiro (Amazona aestiva). Clín. Vet., v.9, p.56-64, 2004.

DEGERNES, L.A.; ROE, S.C.; ABRAMS, C.F. Holding power of different pin designs and pin insertion methods in avian cortical bone. Vet. Surg., v.27, p.301-306, 1998.

GOUVÊA, A.S.; ALIEVI, M.M.; NORIEGA, V. et al. Microplacas de titânio em fraturas de tibiotarso em pombos domésticos. Ciênc. Rural, v.41, p.476-482, 2011.

HATT, J.M. Anesthesia and analgesia of pet birds. Schweiz. Arch. Heilkund, v.144, p.603613, 2002. 


\section{Cherobini et al.}

MARTIN, H.; RITCHIE, B.W. Orthopedic surgical techniques. In: RITCHIE, B.W.; HARRISON, G.J.; HARRISON, L.R. Avian medicine: principles and application. Lake Worth: Wingers, 1994. p.1137-1169.

QUIRÓS, J.R.; GRAMSER, A.G.; PENA, P.L. Valoraciónprequirúrgica de lãs fracturas. Traumatología en aves. Canis Felis, v.1, p.21-37, 2002.
TULLY, T.N. Basic avian bone growth and healing. Vet. Clin. N. Am. Exot Anim. Pract., v.5, p.23-30, 2002.

WISSMAN, M.A. New tools, diagnostics aid in bone and beak repair in birds. Vet. Prod. News, v.11, p.44-45, 1999.

YAMAZOE, K.; HIBINO, C.; KUDO, T.; YANAI, T. The reduction of humeral fracture in pigeons with intramedulary poly (methyl methacrylate) and neutralization plate fixation. $J$. Vet. Med. Sci., v.56, p.739-745, 1994. 